\title{
DARI HOMOTOPIA KE HETEROTOPIA PERUBAHAN KONSTRUKSI RUANG DALAM FIKSI INDONESIA
}

\author{
oleh Pujiharto \\ FIB Universitas Gadjah Mada Yogyakarta
}

\begin{abstract}
This article is about a study aimed at (1) knowing whether there has been a change from epistemological to ontological domination in Indonesian fiction and (2) the repertoire of ontological foregrounding strategies that forms an organized system called the postmodernism poetics of Indonesian fiction and especially those related to space.

To attain its aim, the study applies the postmodernism theory. The theory proposes that the change from modern to postmodern fiction is signaled by a change from epistemological to ontological domination in fiction. Furthermore, to know how the repertoire of postmodernist foregrounding strategies operates in Indonesian fiction, the heterocosm theory is suggested.

The result of the study indicates that a change from epistemological to ontological domination has occurred in Indonesian fiction. In Indonesian fiction, a variety in the repertoire of ontological foregrounding strategies related to space construction has been found. The strategies are interpolation, misattribution, juxtaposition, and migration.
\end{abstract}

Keywords: epistemological, ontological, strategy

\section{A. PENDAhUluan}

Sebagai salah satu entitas yang berproses dalam sejarah, adalah suatu keniscayaan bahwa karya fiksi itu mengalami perubahan. Fiksi Indonesia ditengarai telah mengalami perubahan dari fiksi modern ke fiksi pascamodern. Penanda bagi telah terjadinya perubahan adalah terjadinya perubahan unsurunsur di dalam karya fiksi bersangkutan.

Fiksi adalah hasil konstruksi pengarangnya. Dalam mengkonstruksi karya fiksi pengarang menggunakan strategi-strategi tertentu. Penggunaan strategi-strategi ini tidak bisa dilepaskan dari konteks historis sebelumnya. Oleh karena itu, unsur-unsur yang membangun karya fiksi itu tidak bisa dilepaskan dari segala hal yang pernah ada sebelumnya. Muncullah repertoar-repertoar baru dalam fiksi yang diciptakan pengarang.
Salah satu unsur yang ada dalam fiksi adalah ruang. Ruang dalam fiksi juga mengalami perubahan sejalan dengan diterapkannya strategi-strategi baru dalam pengkonstruksian ruang. Penggunaan strategistrategi baru dan kemunculan ruang-ruang ini menarik untuk diteliti lebih jauh. Sejauh yang dapat diamati, strategi pengkonstruksian ruang yang baru yang menghasilkan ruang-ruang baru tampak mengedepan dalam karya fiksi Indonesia yang terbit tahun 1970-an ke depan, khususnya karya-karya Danarto dan Seno Gumira Ajidarma.

Sehubungan dengan itu, tulisan ini berusaha mengetahui strategi-strategi pengkonstruksian ruang dan ruang-ruang ciptaan baru yang terhasil dari penerapan strategi-strategi tersebut. Karena untuk mencapai tujuan di atas harus pula diketahui strategi pengkonstruksian ruang dan ruang 
yang terbangun sebelumnya, uraian mengenainya pun dipaparkan terlebih dahulu.

Untuk itu tulisan ini menggunakan teori mengenai perubahan yang dominan. Menurut McHale (1991), perubahan dari fiksi modern ke fiksi pascamodern ditandai oleh terjadinya perubahan yang dominan: dari dominan epistemologis ke dominan ontologis. Yang dimaksud dengan yang dominan adalah yang mengatur, menentukan, dan mentransformasikan komponen-komponen yang tampak dengan jelas. Yang dominanlah yang menjamin integritas strukturnya (Jakobson, 1994:41-46). Dengan yang dominan ini akan diketahui proses evolusi yang terjadi dalam karya fiksi. Dengan proses evolusi itu, elemen-elemen yang semula sekunder bisa berubah menjadi penting dan primer, demikian pula sebaliknya. Bentuk-bentuk kepuitisan berubah dan berkembang tidak secara acak, melainkan sebagai hasil sebuah "dominan yang bergeser": ada suatu pergeseran yang terusmenerus dalam saling hubungan di antara bermacam-macam unsur dalam sebuah sistem puitik (Selden, 1991:11).

Sebuah karya fiksi dikatakan bersifat epistemologis bila karya fiksi tersebut memiliki strategi-strategi formal yang secara implisit mengangkat isu-isu tentang aksesibilitas, reliabilitas atau unreliabilitas, transmisi, sirkulasi, dan sebagainya mengenai pengetahuan tentang dunia (McHale, 1992:146). Sebuah karya fiksi dikatakan bersifat ontologis bila karya fiksi tersebut memiliki strategi-strategi formal yang secara implisit mengangkat isu-isu mode keberadaan dunia-dunia fiksional dan penduduknya, dan/atau merefleksikan pada pluralitas dan diversitas dunia-dunia, apakah "nyata", mungkin, fiksional, atau apa yang kamu miliki (what-have-you) (McHale, 1992:147).

Namun, dengan pengertian ontologi yang demikian hanya bisa digambarkan repertoar strategi-strategi yang sama, bahwa seluruh pengedepanan yang dilakukan para pengarang pascamodernis adalah merupakan sikap ontologis. Tidak bisa digambarkan bagaimana pengedepanan sifat ontologis itu diselesaikan, strategi-strategi apa yang telah disebarkan. Untuk bisa melakukan hal itu terlebih dahulu perlu dikemukakan secara garis besar tema ontologis klasik dalam puitika yang berkenaan dengan pembangunan ruang di atas, yaitu teori heterokosmos.

Sebelum diuraikan teori heterokosmos, terlebih dahulu diuraikan beberapa konsep yang dipergunakan, yaitu ontologi, repertoar, strategi, pengedepanan, latar belakang, dan pengedepanan.

Yang dimaksud dengan ontologi adalah deskripsi teoretis tentang sebuah semesta ( $a$ theoretical description of a universe). Dengan a universe (sebuah semesta) -bukan the universe (semesta besar) - maka dimungkinkan untuk mendeskripsikan beberapa semesta. Hal itu berarti bahwa secara potensial terdapat pluralitas semesta (McHale, 1991:27).

Repertoar adalah konvensi-konvensi yang perlu untuk pemantapan suatu situasi. Repertoar terdiri atas seluruh teritori yang familiar di dalam teks. Repertoar ini barangkali ada dalam bentuk acuan-acuan pada karyakarya yang lebih awal, atau pada norma-norma sosial dan historis, atau pada seluruh kebudayaan dari yang teks itu muncul (Iser, 1987:69). Repertoar teks disusun dari materi yang diseleksi dari sistem sosial dan tradisitradisi sastra. Seleksi norma-norma sosial dan alusi-alusi sastra ini menyusun karya di dalam suatu konteks referensial yang sistem ekuivalensinya harus diaktualisasikan (Iser, 1987:86). Dalam konteks penelitian ini, repertoar dimaksud ada dan disusun dengan mendasarkan pada acuan karya-karya yang telah lalu. Karya dimaksud menunjuk pada teori ontologi fiksi, yaitu teori heterokosmos. Ontologi fiksi yang dikemukakan dalam teori heterokosmos tidak lagi mewujud dalam bentuk asli sesuai dengan konteks kelahirannya, tetapi muncul dalam fiksi Indonesia dengan wujud baru dan konteks yang baru pula.

Strategi adalah prosedur-prosedur yang diterima oleh pembicara dan penerima dalam ucapan performatif (Iser, 1987:69). Strategi sebagaimana dikemukakan Iser 
(1987:86) berfungsi untuk mengorganisasi pengaktualisasian repertoar, dan strategistrategi itu mengerjakan hal yang demikian itu dalam cara-cara yang berragam.

Sementara itu, repertoar yang diaktualisasikan dengan strategi di atas muncul dari latar belakang (background) tertentu hingga mengedepankan (foreground) elemen terpilih. Dengan demikian, proses seleksi secara tak terhindarkan menciptakan hubungan latar belakang-pengedepanan (backgroundforeground), dengan elemen terpilih muncul pada pengedepanan dan konteks aslinya pada latar belakang. Tanpa hubungan yang demikian, elemen terpilih akan muncul tanpa arti (Iser, 1987:93).

Namun, latar belakang dan pengedepanan dalam tulisan ini muncul dalam dua hubungan, yaitu (1) hubungan antara fiksi modern dengan fiksi pascamodern dan (2) hubungan antara ontologi fiksi dalam konteks yang lama dengan repertoar strategi pengedepanan ontologis yang baru. Pada (1) terjadi hubungan yang menunjuk pada terjadinya perubahan sifat yang dominan: dari sifat epistemologis ke sifat ontologis. Lebih lanjut, perubahan yang dominan yang telah diuraikan dijadikan dasar bagi pengedepanan sifat ontologis. Dalam konteks ini, sifat epistemologis yang merupakan sifat yang dominan pada fiksi modern hanya dijadikan sebagai latar belakang bagi pengedepanan sifat ontologis yang merupakan sifat yang dominan pada fiksi pascamodern.

Selanjutnya, sifat ontologis yang dikedepankan pada (1) adalah sifat ontologis dalam pengertian umum. Agar bisa dideskripsikan repertoar strategi-strategi pengedepanan sifat ontologis yang spesifik terlebih dahulu diuraikan ontologi yang telah dikemukakan dalam teori heterokosmos. Uraian mengenai sifat ontologis dalam teori heterokosmos ini merupakan latar belakang bagi pengedepanan repertoar strategi pengedepanan sifat ontologis yang muncul dalam fiksi Indonesia. Dalam pengertian seperti itulah hubungan (2) di atas dipahami.

Dalam melihat karya fiksi, pandangan heterokosmos membedakan antara yang nyata dengan yang fiksi, dunia fiksi dianggap sebagai otherness, terpisah dari dunia pengalaman nyata. Implikasinya, terdapat batas wilayah ontologis di antara keduanya. Akan tetapi, karena hal itu bukan berarti tidak ada kaitan antara dunia nyata dengan dunia fiksi, maka dibutuhkan teori heterokosmos yang dimodifikasi, yaitu teori yang mengakui adanya semacam tumpang tindih tertentu atau interpenetrasi antara heterokosmos dan yang nyata. McHale (1991:28) mengacu pada pendapat Benjamin Hrushovsky yang mengatakan bahwa semua teks sastra mengandung struktur acuan yang berlapis (double decker). Teks sastra paling tidak memproyeksikan satu bidang acuan yang bersifat internal, sebuah semesta atau kontinum semantik (secara bebas, sebuah dunia) yang dikonstruksi di dalam dan oleh teks itu sendiri. Selain itu, teks-teks itu mau tidak mau mengacu keluar dari bidang internalnya menuju satu bidang referensi eksternal: dunia yang objektif, tubuh fakta historis, atau teori ilmiah, ideologi atau filsafat, teks-teks lain, dan sebagainya.

\section{B. PERUBAHAN KONSTRUKSI RUANG DALAM FIKSI INDONESIA}

\section{a. Ruang Homotopia dalam Fiksi Indonesia}

Sebagaimana dikemukakan di atas, yang dominan pada fiksi modern adalah sifat epistemologisnya. Demikian pula halnya dengan ruang di dalamnya. Berkaitan dengan strategi pengkonstruksiannya, konstruk ruang dalam fiksi modernis diorganisasi di sekitar subjek yang mempersepsi, entah oleh tokoh atau cara memandang yang diadopsi oleh narator yang tidak kelihatan (McHale 1991:45). Pengkonstruksian ruang dengan cara ini mengedepan dalam berbagai wujud: penampakan versus realitas, multiplisitas perspektif, distorsi hasrat dan kenangan, dan sejenisnya (McHale, 1991:43). Ruang yang dikonstruksi dengan cara yang demikian disebut dengan homotopia.

Pengkonstruksian ruang dengan cara yang demikian mengedepan dalam fiksi Indonesia modern. Sekedar sebagai contoh di 
bawah ini diuraikan pengedepanan ruang dalam wujud multiplisitas perspektif yang tampak dalam Sitti Nurbaya (1922)', khususnya berkaitan dengan penggambaran Gunung Padang. Di satu sisi, Gunung Padang diorganisasi dengan mengadopsi cara pandang narator yang tidak kelihatan.

Gunung Padang yang tingginya kira-kira $322 \mathrm{M}$, ialah ujung sebelah utara gunung-gunung rendah, yang memanjang di sebelah selatan kota Padang. Itulah sebabnya, maka pinggir laut di situ pada beberapa tempat curam dan jarang didiami orang. Asalnya gunung-gunung ini pada Bukit Barisan, yang memanjang di tengah-tengah pulau Sumatera dari ujung barat laut ke ujung tenggara. Gunung Padang adalah sebagai suatu cabang Bukit Barisan itu, yang menganjur ke barat, sampai ke tepi laut kota Padang.

(Rusli, 2001:36)

Di sisi yang lain, narator yang sama mengadopsi cara pandang orang Belanda mengenai gunung yang sama.

Orang Belanda menamai Gunung Padang ini Apenberg (gunung kera), sebab di puncaknya banyak kera yang jinak-jinak, yang memberi kesukaan kepada mereka yang mendaki gunung itu. Apabila dipanggil dan diberi pisang, datanglah kera-kera itu berpuluh-puluh banyaknya, memperebut-rebutkan makanan ini. Kera yang besar-besar, terkadangkadang berani merampas pisang atau makanan lain, dari tangan orang.

(Rusli, 2001:36-37)

Namun, pengorganisasian ruang oleh narator dengan cara pandang orang Belanda itu kadang juga tumpang tindih dengan cara pandang orang Padang.

Sungguhpun demikian, tak ada orang yang berani berbuat apa-apa atas kera-kera ini, sebab pada sangka anak negeri kota Padang, kera-kera itu keramat, tak boleh diganggu-ganggu. Jika dibunuh, tentulah yang membunuh itu akan mati pula, dan jika ditangkap, tentulah yang menangkap itu tak dapat mencari jalan pulang. Ada pula yang bersangka, bahwa kera-kera itu asalnya dari sekalian orang yang telah mati, yang dikuburkan di gunung itu, hidup kembali sebagai kera jadi-jadian.

(Rusli, 2001:37)

Selain itu, pengorganisasian ruang juga dilakukan dengan menggunakan cara pandang tokoh-tokoh di dalamnya.

Ketika Nurbaya dengan teman-temannya sampai ke pertengahan gunung itu, pada suatu pendakian yang curam, berkatalah ia sambil mencari batu besar tempat duduk, "Alangkah baiknya, apabila ada kendaraan yang dapat ditunggang ke atas ini!"

"Bagaimana? Belum sampai separuh jalan, telah lelah," kata Arifin, seraya membuka buah bajunya, akan melepaskan hawa panas yang keluar daribadannya.

"Kalau tulangku sebesar tanganmu, aku tidak akan berkata sedemikian," jawab Nurbaya.

(Rusli, 2001: 37)

Pengorganisasian ruang dalam wujud multiplisitas perspektif di atas merupakan bagian dari strategi yang dominan dalam novel itu yang mengangkat tema-tema epistemologis, yaitu tema-tema aksesibilitas, reliabilitas atau unreliabilitas, sirkulasi, dan transmisi pengetahuan

\section{b. Zona Heterotopia dalam Fiksi Indonesia}

Konstruk ruang dalam fiksi pascamodern disebut dengan zona heterotopia. 
Konsep 'zona heterotopia' yang biasa dipergunakan oleh kaum pascamodernis untuk menunjuk pengertian dunia-dunia, menurut McHale (1991:44), menunjuk pada ruang heterotopia dalam pengertian Foucault. Heterotopia itu sendiri oleh Foucault (2007:lvi) digambarkan sebagai berikut:

Ada jenis ketidakteraturan yang lebih buruk daripada incongruous (ketidakcocokan), mata rantai bersama benda-benda yang tidak sejalan; saya mengartikan ketidakteraturan yang di dalamnya fragmen-fragmen pada sejumlah besar aturan yang mungkin berkilauan secara terpisah di dalam dimensinya, tanpa aturan atau geometri, heteroclite; ... dalam keadaan semacam itu, benda-benda 'diletakkan', 'ditempatkan', 'disusun', dalam kedudukan yang sangat berbeda satu sama lain yang sangat tidak mungkin untuk menemukan satu tempat kedudukan bagi mereka, membatasi satu lokus umum di bawah mereka semua. ... Heterotopias mengganggu, mungkin karena mereka secara diam-diam menghancurkan bahas a, karena mereka memungkinkannya untuk memberikan nama pada ini dan itu, karena mereka menghancurkan 'sintaks' lebih lanjut, dan bukan hanya sintaks dengan mana kita membangun kalimat-kalimat tetapi juga sintaks yang kurang jelas yang menyebabkan kata-kata dan benda-benda (bersebelahan dan bertentangan satu sama lain) 'berkumpul bersama-sama'.

Dengan pengertian di atas, zona heterotopia tulisan pascamodern tidak dapat ditata dengan cara yang sama dengan penataan ruang dalam fiksi modernis atau realis. Zona heterotopia tulisan pascamodernis tidak dikonstruksi tetapi didekonstruksi oleh teks, atau dikonstruksi sekaligus didekonstruksi pada saat yang sama (McHale, 1991:45). Dengan cara pengkonstruksian yang seperti itu, yang kemudian muncul adalah pluralitas ruang, dan yang kemudian mengedepan adalah sifat ontologisnya.

Agar dapat diketahui bagaimana pengedepanan itu dilakukan dan strategi apa yang digunakan, pengkonstruksian ruang di bawah ini haruslah dikaitkan dengan teori heterokosmos yang telah dikemukakan.

Ada empat strategi dalam membangun zona heterotopia, yaitu (1) penjajaran (juxtaposition), (2) penyisipan (interpolation), (3) pelapisan (superimposition), dan (4) misatribusi (misattribution) (McHale, 1991:45). Keempat strategi itu memunculkan zona yang dijajarkan, zona yang disisipkan, zona yang dilapiskan, dan zona yang memparodikan.

Dalam fiksi Indonesia, terdapat tiga jenis strategi pembangunan zona heterotopia, yaitu strategi penyisipan, misatribusi, dan penjajaran. Selain ketiga strategi tersebut, dalam fiksi Indonesia ada strategi lain yang belum disebutkan McHale, yaitu strategi pemindahan.

\section{Strategi Penyisipan}

Sesuai dengan namanya, penyebaran strategi ini dilakukan dengan cara menciptakan zona yang disisipkan. Yang dimaksud dengan zona yang disisipkan menunjuk pada ruang asing (tidak dikenal) di dalam ruang yang akrab atau di antara dua area ruang yang berdekatan yang tidak ada "antara"nya (McHale, 1991:46). Dengan demikian, zona yang disisipkan hanya ada di dalam teks fiksi yang diciptakan oleh pengarang.

Zona yang disisipkan ini mengedepan dalam "Negeri Kabut" (dalam Negeri Kabut, 1996), "Bayang-Bayang Elektra" (dalam Dilarang Menyanyi di Kamar Mandi, 2006), dan Negeri Senja (2003) karya Ajidarma.

Negeri Kabut dalam cerpen "Negeri Kabut" (1996) adalah sebuah negeri yang biasa disinggahi oleh mereka yang senang mengembara dari tempat yang satu ke tempat yang lain. Meskipun demikian, para pengembara itu tidak pernah bercerita 
mengenai negeri itu (Ajidarma, 1996:7). Tokoh aku dalam cerpen itu juga belum pernah menemukan keterangan tentang Negeri Kabut, belum pernah melihat brosur tentang negeri itu, belum pernah membaca penjelasan apa pun dalam ensiklopedi, tidak juga secuil-secuil dalam internet, dan bahkan juga tidak pernah menemukannya di dalam peta (Ajidarma, 1996:2). Negeri Kabut adalah tempat yang tidak tercatat dalam sejarah, dan bahkan tidak pernah tercatat sebagai negeri yang hilang (Ajidarma, 1996:5).

Ketika sampai di negeri itu, tokoh aku mendapati sebuah kampung yang bagaikan begitu saja tumbuh dari dalam tanah. Di kampung itu terdapat orang tua, orang muda, anak-anak yang semuanya duduk di rumahrumah panggung, mengelilingi api unggun, dan dari situ terdengar seorang tua bercerita yang didengarkan oleh mereka semua (Ajidarma, 1996:7-8). Di kampung itu yang didapati adalah orang-orang yang berwajah bersih dan suci (Ajidarma, 1996:10).

Dalam perjalanan meninggalkan kampung itu tokoh aku juga mendapati orangorang dengan mata dan wajah yang bersih tanpa persoalan, mendapati suasana yang menyejukkan, mendapati seorang gadis yang menari-nari mengikuti suara petikan tena yang didengarnya, dan juga mendapati pasar yang meskipun di dalamnya banyak orang yang menjual barang-barang miliknya tetapi sunyi. Karena di kampung dan sekeliling jalan yang dilewatinya itu dipenuhi kabut yang terus bergerak, orang-orang, gadis, dan pasar itu kadang kelihatan kadang hilang tertutup kabut.

Hingga sampai ke Negeri Kabut, terlebih dahulu tokoh aku melewati bukit yang tidak disebutkan di mana tetapi terasa akrab dan telah dikenal (Ajidarma, 1996:2). Tokoh aku melewati tempat-tempat yang dilewati orangorang yang berasal dari Hmong dan berbicara dengan mereka dengan bahasa Thai (Ajidarma, 1996:5), diajak bicara oleh penjaga wilayah perbatasan dengan bahasa Karen (Ajidarma, 1996:7). Ketika sudah keluar dari Negeri Kabut, tokoh aku melewati sebuah kuil di tempat terpencil dan bertemulah ia dengan pendeta Buddha. Pendeta itu mengatakan bahwa tokoh aku sudah ditunggu seseorang di Sungai Mekong (Ajidarma, 1996:15), sebuah sungai terbesar di Asia yang melintasi negara China, Myanmar, dan Kamboja.

Berbeda dengan zona Negeri Kabut yang tersisip di seputar China, Myanmar, dan Kamboja, zona Negeri Kegelapan dalam cerpen "Bayang-bayang Elektra" disisipkan di antara kota-kota di Jawa Barat, yaitu di seputar Bogor dan Ciawi. Dalam cerpen ini, Elektra yang diceritakan kehilangan bayang-bayangnya berusaha mencari bayang-bayangnya itu. Dalam pencariannya itu, Elektra bertanya pada polisi lalu lintas. Polisi menjawab bahwa bayang-bayangnya berlari cepat sekali menuju ke Negeri Kegelapan. Elektra merasa bahwa dirinya tidak mengenal negeri itu. Akan tetapi, polisi mengatakan bahwa di satu sisi, Negeri Kegelapan adalah "negeri di mana tak ada matahari dan bayang-bayang aman berdekapdekapan dalam kegelapan", di sisi lain, Negeri itu bisa dijangkau dengan melewati jalan tol arah ke kiri yang arah itu berbeda dengan arah ke Bogor dan arah ke Ciawi. Dengan demikian, zona Negeri Kegelapan merupakan zona yang bersifat fiktif, tetapi untuk menempuhnya melewati lokasi yang konkret. Kefiktifan Negeri Kegelapan menunjukkan bahwa zona itu hanya ada dalam teks cerpen itu. Namun, karena zona itu bisa ditempuh dengan melewati lokasi yang konkret, maka keberadaannya pun disisipkan di antara lokasi-lokasi yang konkret itu.

Bila Negeri Kabut adalah zona yang disisipkan di seputar China, Thailand, Myanmar, Negeri Kegelapan disisipkan di seputar Bogor dan Ciawi, Negeri Senja dalam novel Negeri Senja tidak jelas terletak di mana, tidak jelas batas-batasnya dengan lokasi-lokasi tertentu yang tercatat di dalam peta dan telah dikenal akrab.

Meskipun demikian, ada perbedaan antara Negeri Senja dan lokasi yang bukan Negeri Senja. Lokasi di luar Negeri Senja, yaitu yang dilewati tokoh aku dalam pengembaraannya hingga suatu ketika sampai ke Negeri Senja, adalah dunia yang di dalamnya 
matahari terbit di timur dan tenggelam di barat dan dengan demikian dapat dikenal dengan mudah, semisal negeri, kota, kampung, hutan, lautan, gunung, dan gurun (Ajidarma, 2003:4). Karenanya, lokasi itu pasti menunjuk ke alam nyata dan ada di dalam peta.

Adapun Negeri Senja yang suasananya selalu senja dikatakan tidak terdapat di dalam peta (Ajidarma, 2003:8). Di bagian lain digambarkan bahwa Negeri Senja sulit ditunjukkan letaknya di mana, setidaknya kirakira di sebelah mana, dalam peta dunia, karena negeri itu sepertinya saja berada di bumi, tetapi lain dimensi adanya - bisa didatangi dari mana saja, tetapi tidak mungkin dipastikan tempatnya (Ajidarma, 2003:224). Karena tidak ada di dalam peta, Negeri Senja pun muncul secara tiba-tiba saja di hadapan tokoh aku.

Begitulah, suatu ketika dalam perjalananku tibalah aku di Negeri Senja, yang seperti tiba-tiba saja muncul di hadapanku setelah menyeberangi sebuah gurun selama dua minggu.

(Ajidarma, 2003:5)

Dengan dinyatakan "seperti tiba-tiba saja muncul di hadapanku", maka yang terjadi itu tidaklah bisa dijelaskan dengan dasar-dasar epistemologis. Proses "tiba-tiba saja muncul" merupakan gambaran mengenai mode keberadaan (mode of being), suatu semesta baru, yaitu zona yang disisipkan. Karena kemunculannya dalam dunia kehidupan seharihari yang ada secara nyata dan dengan demikian ada di dalam peta, Negeri Senja adalah zona yang disisipkan di dalam ruang yang akrab dan telah dikenal baik.

\section{Strategi Misatributif}

Strategi misatributif melakukan penyebarannya dengan cara menciptakan zona misatributif. Yang dimaksud dengan zona misatributif menunjuk pada zona yang merupakan hasil parodi terhadap ruang yang ada di dunia nyata (McHale, 1991:48). Sebagai bentuk parodi, zona ini menghadirkan dan memberikan gambaran yang berbeda dan bahkan bertentangan dengan ruang dunia nyata yang diparodikan. Zona ini mengedepan dalam cerpen berjudul "Labyrinth" (terkumpul dalam Godlob, 1974: 100-113) dan "Paris Nostradamus" (terkumpul dalam Setangkai Melati di Sayap Jibril, 2001:29-52) karya Danarto, dan juga dalam cerpen "Sepotong Senja Untuk Pacarku" (terkumpul dalam Sepotong Senja Untuk Pacarku, 2002:3-18) karya Ajidarma.

Dalam cerpen "Labyrinth" diceritakan bahwa Ahasveros yang dikejar oleh pasukan Yahudi dan Arab berlari dan dalam pelariannya itu ia mendaki ke sebuah bukit putih. Ia kemudian masuk lewat pintu batu kecil yang ada di bukit itu. Di dalamnya ada ruang yang disebut dengan "Cerminnya cermin". Di dalam ruang itu diceritakan mayat-mayat bisa bergerak, mayat-mayat bisa saling bertegur sapa antara yang satu dengan yang lainnya, mayat-mayat bisa menembak, mayat-mayat bisa lepas sendiri kepala, tangan, dan kakinya, mayat-mayat bisa menguburkan mayat yang lainnya. Sebagai tempat yang bernama "Cerminnya cermin", apa yang terjadi di tempat itu sebenarnya merupakan bentuk parodi dari yang sesungguhnya terjadi di dunia nyata, bahwa orang-orang di dunia nyata yang saling menyerbu satu dengan lainnya pada dasarnya adalah mayat-mayat.

Bau busuk mayat kembali menusuk-nusuk hidungnya. Lalu ia berdiri dan dipandangnya satu persatu mayat itu. Ia kaget sekali, karena rasanya ia kenal wajah-wajah mayat itu. Bukankah ini wajah-wajah prajuritprajurit yang mengejar-ngejarnya dan menembakinya barusan?!! Pakaian seragamnya, ikat lehernya, sepatunya... ia kenal betul. Nah, ini tampang orang yang menegornya ketika ia menginjak jalan perbatasan antara dua kubu itu. Nah, ini orang yang pertama kali mengokang senapannya. Nah, ini .... Nah, ini.... Oh, mengherankan sekali! 
Aku jadi ingat seluruhnya. Serunya berkali-kali. Lalu ia berlari ke luar pintu. Ia menjenguk ke bawah, dilihatnya prajurit yang mengejarnya itu mendirikan kemah. Rupanya mereka tetap gigih hendak menangkapnya. Lalu Ahasveros kembali masuk ke dalam dan dilihatnya mayat-mayat itu dalam posisi mendirikan kemah pula. Melihat ini Ahasveros merasa perutnya tak kuat lagi, lalu ia muntah-muntah. Lalu ia berjalan ke arah di sebalik sana. Dilihatnya mayat ibu-ibu dan anakanak di atas onggokan besar.

(Danarto, 1974:109)

Dalam cerpen "Paris Nostradamus" diceritakan bahwa Paris yang sesungguhnya digambarkan telah hancur akibat diserbu kaum teroris. Dalam setiap harinya di kota itu selalu terdengar suara tembakan. Suasana di kota itu pun selalu mencekam. Semua orang kemudian menggunakan pakaian antipeluru dan antiteroris untuk melindungi dirinya dari tembakan dan teror. Jauh-jauh hari, kenyataan itu sebenarnya sudah diramalkan oleh Nostradamus. Walikota Paris yang mempercayai ramalan itu kemudian mengkampanyekan kepada rakyat Paris mengenai pentingnya dibangun kota duplikat Paris. Ide itu pun disetujui. Kota duplikat Paris pun kemudian dibangun, yaitu pada tujuh lapis ke bawah dari permukaan bumi. Tokoh aku, yang datang ke kota Paris bermaksud menghadiri pertemuan anggota keluarga besarnya - kedua orang tuanya tinggal di Paris - mendapati Paris dalam keadaan sangat mencekam dan mengerikan karena dikuasai kaum teroris. Namun, setelah sebelumnya melewati proses yang berliku-liku, akhirnya ia bisa memasuki kota duplikat Paris. Ia mendapati kota duplikat Paris itu sama persis dengan Paris yang sesungguhnya ketika dalam keadaan normal. Sementara kota Paris itu sendiri pada saat itu telah hancur karena terkena bom nuklir dan dianggap sebagai kota maya yang telah lewat.
"Kita sekarang ini hidup di kota duplikat Paris."

"Kota duplikat Paris?" seru saya keheranan.

"Paris di atas permukaan tanah yang bersimbah terorisme yang barusan Anda rasakan itu sesungguhnya kota maya."

“Kota maya?" seru saya makin keheranan.

"Kota yang sudah tidak ada. Paris yang telah lewat."

"Paris yang telah lewat?"

"B om nuklir telah memusnahkan Paris satu menit menjelang Anda mendarat di Orly."

(Danarto, 2001:51)

Zona kota duplikat Paris di atas tentu tidak mungkin ada dalam kenyataan. Zona yang hanya ada dalam teks cerpen itu dibuat oleh pengarangnya dalam rangka memparodikan keadaan kota Paris.

Zona misatributif yang mengedepan dalam cerpen "Sepotong Senja Untuk Pacarku" memparodikan senja dengan zona senja yang ada di bawah tanah yang untuk menujunya tokoh aku harus melewati sebuah goronggorong. Senja yang ada di bawah tanah itu sama persis dengan senja yang di atas permukaan tanah. Namun, bila di dalam senja yang di atas tanah ada manusia, ada tikus, ada burung, di dalam senja yang di bawah tanah tidak ada dan burung yang ada pun hanya ilustrasi saja, bukan burung sungguhan (Ajidarma, 2002:15). Sukab yang terperosok ke dalam senja yang ada di bawah tanah itu karena telah memotong senja yang sesungguhnya sebesar kartu pos dan kemudian karena diprotes banyak orang ia kemudian dikejar-kejar polisi, memotong senja yang di bawah tanah itu dan ketika keluar darinya, naik ke senja yang sesungguhnya, ia memasangkan potongan itu ke senja yang sesungguhnya yang telah dipotongnya sebesar kartu pos. Karena pas ukurannya, senja yang sesungguhnya pun normal kembali. 


\section{Strategi Penjajaran}

Dalam melakukan penyebarannya, strategi ini melakukan penjajaran antara zona fiksi dengan ruang dunia nyata. Zona yang dijajarkan terjadi ketika ruang yang diatlaskan di dunia nyata atau ditunjukkan ensiklopedi sebagai ruang yang tidak berhubungan dan terputus ketika dijajarkan di teks tertulis menjadi sebuah zona (McHale, 1991:45). Zona yang dijajarkan ini mengedepan dalam cerpen Ajidarma yang berjudul "Di Tepi Sungai Parfum" (1995) (terkumpul dalam Negeri Kabut, 1996).

Di dalam cerpen itu digambarkan pengembaraan tokoh aku yang telah tiba di tepi Sungai Parfum. Sungai itu sendiri merupakan zona batas antara dunia nyata dan dunia maya. Sebelumnya, tokoh aku telah mengarungi jalan berliku dunia nyata.

Dunia nyata dimaksud, meskipun tidak secara eksplisit disebutkan di mana letaknya di dalam atlas, gambaran mengenainya terasa sangat dekat, akrab, dan dikenali dengan baik oleh tokoh aku sebagaimana manusia pada umumnya mengenalnya.

Aku berdiri di tepi sungai. Udara sangat panas, matahari terik membara, dunia nyata yang celaka. Sepatuku sudah jebol-jebol dan kakiku sudah pecah-pecah mengarungi perjalanan panjang dari kenyataan satu ke kenyataan lain.

(Ajidarma, 1996:62)

Dengan gambaran di atas, pastilah ia mengacu ke lokasi yang secara nyata ada dan tentulah tercatat di atlas. Dalam dunia nyata itu tidak disebutkan wilayah-wilayah tertentu sehingga tergambarkan ada batas antara wilayah A dengan wilayah B misalnya, tetapi yang disebutkan adalah dunia nyata yang di sebelahnya ada zona batas, yaitu Sungai Parfum, dan di sebelah sungai itu ada dunia maya.

Lebih jauh digambarkan bahwa Sungai Parfum itu berkilat-kilat (h. 66). Di dalamnya ada perahu yang menembus cahaya (h. 61) yang didayung oleh seorang wanita yang cantiknya tidak terkirakan (h. 67) yang mengenakan $a o$ dai (busana tradisional wanita Vietnam) putih transparan (h. 66).

Adapun di dunia maya yang tampak adalah warna hijau, campur kelabu, bayangbayang pohon, dan bayangan putih wanitawanita yang menari (h. 61). Bayang-bayang kehitaman para penari itu bergerak perlahan dilatarbelakangi bola matahari raksasa yang terbenam di balik taman (h. 67).

Mereka yang ingin pergi menyeberang ke dunia maya harus menaiki perahu yang ada di Sungai Parfum. Setelah sampai, mereka akan mengalami kebahagiaan yang kekal dan abadi, tetapi tidak bisa kembali ke dunia nyata (h. 66-67).

Berdasarkan uraian di atas tampak bahwa Sungai Parfum dan dunia maya bersifat ontologis. Zona itu diciptakan oleh pengarang dan hanya ada di dalam cerpen itu saja. Karena kemunculannya dijajarkan dengan dunia nyata, kedua zona disebut dengan zona yang dijajarkan.

\section{Strategi Pemindahan}

Strategi yang belum ditemukan McHale dalam karya fiksi adalah strategi pemindahan. Strategi ini dilakukan dengan cara memindahkan sebuah zona dari lokasi yang satu ke lokasi yang lain. Strategi ini mengedepan dalam cerpen "Sepotong Senja Untuk Pacarku". Selain menggambarkan dipindahkannya senja yang sesungguhnya dengan cara memotongnya sebesar kartu pos ke dalam saku celananya, cerpen itu juga menggambarkan dipindahkannya senja yang ada di bawah tanah dengan cara dipotong sebesar kartu pos ke dalam saku celana yang satunya. Potongan senja yang ada di bawah tanah dipindahkan ke senja sesungguhnya yang telah terpotong, dan potongan senja yang sesungguhnya dikirimkan pada Alina, kekasih Sukab.

\section{PENUTUP}

Uraian di atas menunjukkan bahwa telah terjadi perubahan yang dominan dalam 
fiksi Indonesia: dari dominan epistemologis ke dominan ontologis. Berkaitan dengan pengkonstruksian ruang, dalam fiksi modern mengedepan konstruksi ruang yang disebut dengan homotopia, dan dalam fiksi pascamodern disebut dengan heterotopia. Zona heterotopia ini meliputi zona yang disisipkan yang merupakan hasil dari strategi penyisipan; zona misatributif yang merupakan penerapan strategi misatributif; zona yang dijajarkan yang merupakan hasil penerapan strategi penjajaran; dan zona yang dipindahkan yang merupakan penerapan strategi pemindahan.

\section{DAFTAR PUSTAKA}

Ajidarma, Seno Gumira. 1996. Negeri Kabut, Jakarta: Grasindo. 2002. Sepotong Senja untuk Pacarku, Jakarta: Gramedia. . 2003. Negeri Senja, Jakarta: Kepustakaan Populer Gramedia. . 2006. Dilarang Menyanyi di Kamar Mandi, cet. ke-3, Yogyakarta: Galang Press.

Danarto. 1974. Godlob Kumpulan Cerita Pendek, Rombongan Dongeng dari Dirah.
2001. Setangkai Melati di Sayap Jibril, Yogyakarta: Bentang Budaya

Foucault, Michel. 2007. Order of Thing Arkeologi Ilmu-Ilmu Kemanusiaan, diterjemahkan dari The Order of Things An Archaeology of Human Sciences, Yogyakarta: Pustaka Pelajar.

Iser, Wolfgang. 1987. The Act of Reading A Theory of Aesthetic Response, Baltimore and London: The Johns Hopkins University Press.

Jakobson, Roman. 1994. "The Dominant", Language in Literature, Krystyna Pomorska, ed., cet. ke-5, United States of America: The Jacobson Trust

McHale, Brian. 1991. Postmodernist Fiction, London and New York: Routledge.

Rusli, Marah. 2001. Sitti Nurbaya, cetakan ketigapuluh lima, Jakarta: Balai Pustaka.

Selden, Raman. 1991. Panduan Pembaca Teori Sastra Masa Kini, diterjemahkan dari $A$ Reader's Guide to Contemporary Literary Theory oleh Rachmat Djoko Pradopo dan disunting oleh Imran T. Abdullah, Yogyakarta: Gadjah Mada University Press. 